\title{
Guerrilla Warfare in Katanga: The Sanga Rebellion of the 1890s and Its Suppression
}

\author{
Giacomo Macola \\ University of Kent (g.macola@kent@ac.uk) \\ School of History, Rutherford College \\ University of Kent CT27NX
}

\author{
with \\ Jack Hogan

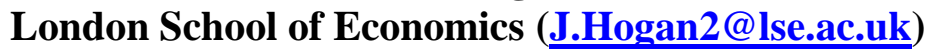

\begin{abstract}
This article discusses the origins and development of the Sanga insurgency of the 1890s with a view to demonstrating that, contrary to commonly held stereotypes, pre-colonial warfare was neither simple nor unchanging. Its tactics, it is argued here, repay the sort of close analysis commonly reserved for other typologies and theatres of war. The Yeke, against whose exploitative system of rule the Sanga and their allies rose up in 1891, survived the onslaught by entering into a strategic alliance with Lofoi, a newly established station of the Congo Free State, and its limited contingent of regular Force Publique troops. An in-depth examination of the joint Yeke-Force Publique counterinsurgency campaign leads to the conclusion that the novelty of the 'small wars' that accompanied the Scramble for Africa should not be overstated. In southern Katanga and, by implication, elsewhere, these confrontations were shaped by processes of mutual borrowing in which African military practices and even political aims were not necessarily subordinate to European ones.
\end{abstract}

\section{Key words}

guerrilla, Msiri, Mukanda Bantu, pre-colonial, Scramble for Africa, Katanga, Yeke, Sanga

\section{Introduction}

The study of warfare in Africa remains altogether undeveloped. As a result of this dearth of scholarship, African military history has yet to be fully decolonized, and the sub-field remains 'perhaps the last bastion of the kind of distorted Eurocentric scholarship that characterised African studies before the 1960s.' ${ }^{1}$ Richard Reid's remarks apply with special force to the precolonial period, whose conflicts have rarely - if ever - been deemed worthy of detailed operational analysis, even in such instances where the available evidence would readily lend itself to this kind of treatment. ${ }^{2}$ Drawing on an underutilized body of sources - primarily the records of the Plymouth Brethren (PB) missionaries, in Katanga since 1886, and the personal correspondence of Clément Brasseur, the Lofoi chef de poste in 1893-1897 ${ }^{3}$ this article examines the dynamics of one specific insurgency on the cusp of the colonial occupation of Katanga with a view to demonstrating that, contrary to commonly held stereotypes, precolonial warfare was neither simple nor unchanging. Its tactics and strategies, it is argued here, repay the sort of close analysis commonly reserved for other typologies and theatres of war.

Since the Sanga insurgency was eventually suppressed by a newly-minted Euro-African coalition, this paper also aims to intervene in debates about the military aspects of the Scramble 
for Africa. Patterns of African resistance to the colonial conquest, of course, were a key concern of the first generation of professional historians of Africa. Their analyses, however, were coloured by the politics of the period and, specifically, the attempt to posit a direct connection between so-called 'primary resistances' and later decolonization movements. ${ }^{4}$ For their part, military historians proper have been slower in taking up the study of late nineteenth-century Euro-African confrontations, and their efforts have also been impaired by the tendency to examine these conflicts in isolation from their background and African roots. ${ }^{5}$ Thus, our second objective in this paper is to demonstrate the benefits that accrue from placing the 'small wars' that accompanied the Scramble for Africa in a deeper chronological context than is commonly the case. ${ }^{6}$ Only by so doing - we contend - can the debate about the ultimate nature and ostensible modernity of these military operations be placed on firmer foundations.

A grassroots rebellion against an oppressive foreign elite, Msiri's Yeke, the Sanga insurgency of the 1890s casts important new light on the rise of warlordism in central Africa in the era of global commerce and the manner in which the unprecedented levels of exploitation it brought in its wake were experienced by its victims. It also illustrates the fragility of these new political formations vis-à-vis determined efforts to sever the external links to which they largely owed their economic and military strength. The workings of Msiri's warlord polity, Garenganze, form the subject of the first substantive section of the present article. From an operational point of view, the Sanga insurgency represents an unusually well-documented instance of guerrilla warfare in an environment still unaffected by direct European politicomilitary action. Its origins, development and innovative aspects are examined in the second part of the article. A key watershed in the history of the rebellion was the arrival of Europeanled military forces on the Katangese scene and their alliance with the beleaguered Yeke military. The counterinsurgency campaign jointly carried out by the new partners and the rebels' varied reactions to it are discussed in the third section of the article.

\section{The Yeke Warlord State}

Between the early 1850s and the late 1860s, Msiri, a caravan leader turned conqueror, succeeded in imposing his and his companions' sway over much of present-day Haut-Katanga, a copper-producing district which western Tanzanian traders, including Msiri's own father, Kalasa, had begun occasionally to visit from the 1830s and which had previously formed the western periphery of the Lunda kingdom of Kazembe. ${ }^{7}$ Better equipped than longer-established aristocracies to face the forces of the global trade that was then enveloping the Congo basin, ${ }^{8}$ Msiri's followers - the Yeke - conquered the Sanga and other pre-existing inhabitants of the region, and spawned an innovative type of polity. Typifying the revolutionary changes in governmentality which were then taking place across vast swathes of what would become the Congo Free State (CFS), Garenganze was a warlord state in which the exercise of political power had less to do with religious sanction and hereditary principles than with its ruler's charisma and the systematic use of commercially-driven violence. Owing their wealth and military strength to trade, Yeke state-builders displayed a consistent willingness to resort to forms of extreme compulsion to obtain the ivory and slaves that fed the long-distance exchanges with both the eastern and, increasingly, the western coasts of the continent.

Arab-Swahili trade in southern Katanga might have reached its high point in the late 1860s. Thereafter, its place in the political economy of the new polity was partly taken over by Luso-African and Ovimbundu caravans from present-day Angola. A direct trading link between Garenganze and the Ovimbundu plateau was inaugurated in about 1870 by a João Baptista Ferreira, who responded to some earlier Yeke entreaties and supplied Msiri 'with powder, guns, and cloth in exchange for ivory. ${ }^{9}$ Yeke and other sources clarify that, unlike in the case of the eastern trade towards the Swahili coast, the Yeke did not merely await the arrival 
of foreign merchants in their capital, but actively organized independent westbound caravans to transport the ivory and slaves accumulated by Msiri. ${ }^{10}$ Already in 1875 , Benguela, the terminus of Ovimbundu trade routes on the Angolan coast, was the principal port of entry for the Portuguese- and Belgian-made muskets and gunpowder which Angolan caravans brought to Msiri capital, Bunkeya, after negotiating Chokwe and Luvale countries and crossing the upper Lualaba to the south of the Upemba depression (see map). ${ }^{11}$

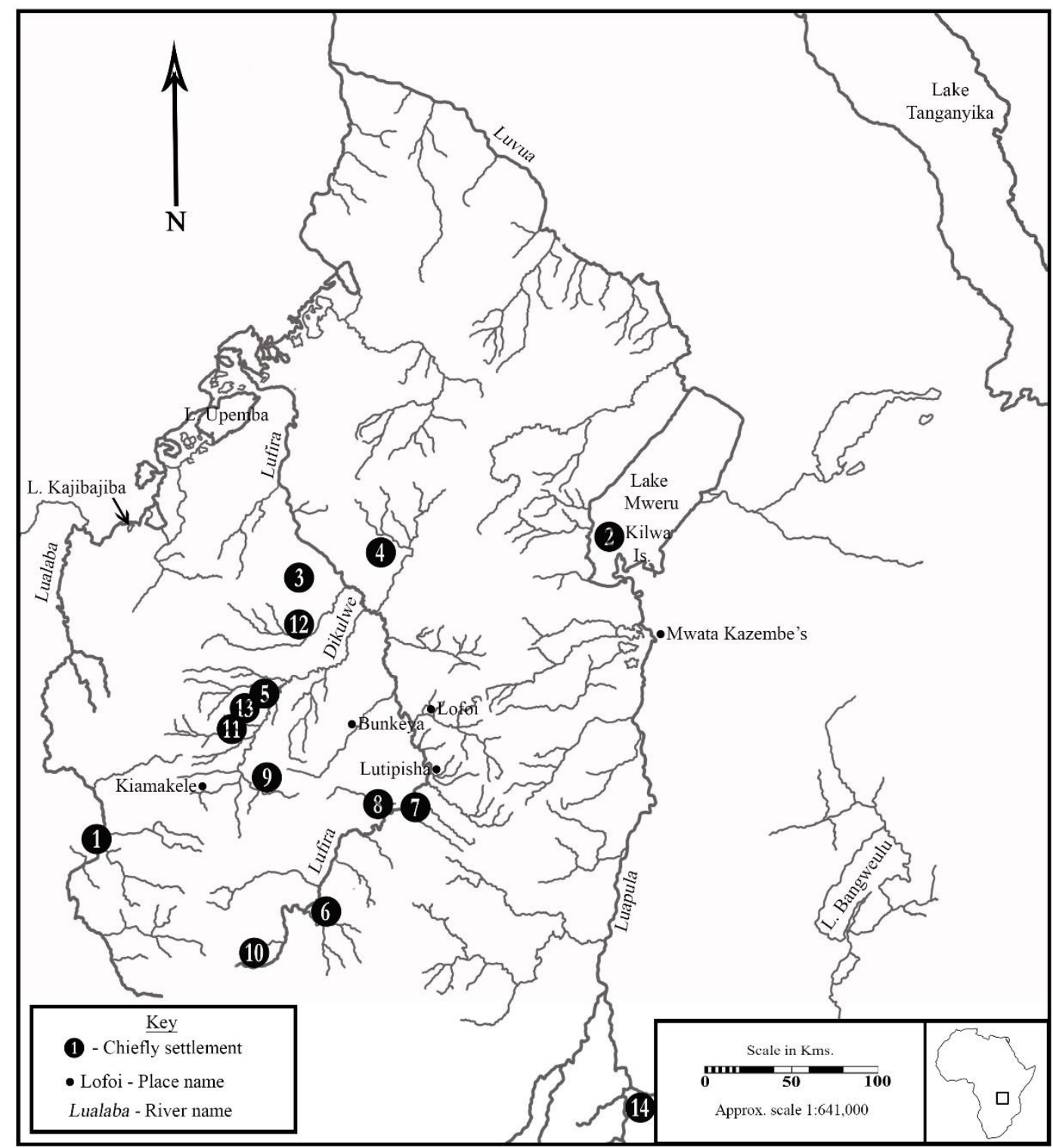

Katanga in the 1890s

1. Kazembe of the Lualaba

2. Shimba

3. Kalera

4. Mukana

5. Mulowanyama (to late 1895)

6. Katanga

7. Mwashya
8. Mutwila

9. Kalunkumia

10. Ntenke

11. Mwenda Mukoshi

12. Kalala Ngombe

13. Kasangula

14. Kiwala 
At the apogee of his power in the 1880s, Msiri acted very much like a merchant prince, lording it over Bunkeya - a bustling commercial hub located at the crossroad of several regional and long-distance exchange networks ${ }^{12}$ - and exerting tight control over the kingdom's external trade. Central privileges were especially rigidly enforced in the case of the ivory and slave trades. Not only were ivory and slaves exhaustible resources, but they also represented the most highly sought-after items of trade among Ovimbundu gun-dealers. Thus, by centralizing in his hands the commerce in these two commodities, Msiri was also able to impose a practical monopoly over the acquisition and distribution of guns. By 1884, the Ovimbundu-run trade in guns and gunpowder had resulted in Msiri being equipped with an impressive force of ' 2,000 or 3,000 flintlock muskets'. ${ }^{13}$ This arsenal exceeded that of any other regional power, and its 'considerable' size was well-known to neighbouring peoples. ${ }^{14}$

To be sure, the creation of dependencies and relations of reciprocity through the circulation of foreign goods was part of Msiri's political repertoire; yet such institutions of rule were largely confined to the Yeke and Yekeized elites. Conversely, the bulk of Garenganze's subject peoples constituted a mass of primary producers to be preyed upon. Resource extraction in the heartland of the polity and even some of the more distant peripheral regions acquired over the course of the 1870s-1880s was ensured by a network of centrally-appointed officials, the banangwa (sing. mwanangwa). Frequently chosen from within the ranks of Msiri's close patrilineal relatives, Yeke banangwa served as tribute collectors and also as military and caravan leaders. ${ }^{15}$ Insofar as ivory and slaves were concerned, the Yeke devised a 'system of compulsory production quotas' destined to increase their ruler's access to such indispensable commodities. ${ }^{16}$ Msiri's exactions - what Delcommune, the leader of one of the first Belgian expeditions to Katanga, called the 'insatiable avidity of the king' in demanding ivory and slaves for sale to the Ovimbundu ${ }^{17}$ - caused real hardship to subject peoples. Chief Mapanda - for instance - complained to PB missionary Crawford that Msiri had once given him only 'a paltry four yards of cloth' and 'no remuneration whatever to his men' in return for a massive tribute of 'forty teeth of ivory'. ${ }^{18}$ In another instance, a seeming shortfall in the expected ivory payment late in 1889 led to the execution of an unnamed local leader by the son of Dikuku, Msiri's brother. 'In a day or two' - wrote another missionary - 'the head of this poor unfortunate, with those of all his male villagers, will be presented to Msidi with great pomp and ceremony. The females and children will become the slaves of the Vayeke.' ${ }^{19}$

Besides tribute, raids were the principal means through which captives were obtained for both trading and internal purposes. Carried out by comparatively heavily-armed, semiprofessional infantrymen, slave forays punctuated the economic life of Garenganze and accounted for the spread of violence and the overall militarization of society in Katanga in the latter part of the century. The PB missionary Arnot, the first European to spend a long period of time among the Yeke, remarked in August 1886 that Msiri was 'constantly sending out war parties to the countries all round' ${ }^{20}$ These war parties - he explained elsewhere - brought back '[1]arge numbers of slaves' who were 'sold chiefly to Arab traders from Zanzibar and to Ovimbundu traders from Bihé. Strong young men' - he concluded - 'have been sold for ten or twelve yards of cotton cloth. ${ }^{21}$ Women were probably more frequently kept in Bunkeya and surrounding areas with a view to exploiting their labour and reproductive potential. ${ }^{22}$ The pervasiveness of slave-raiding activities accounts for the fact that the 'proportion of women to men [was] very unequal' in Bunkeya and for the capital's oft-remarked-upon cosmopolitan nature. ${ }^{23}$ For ' $[\mathrm{w}]$ hat means the babel of tongues heard in this country, if not that Msidi's war parties have brought in from nearly every point of the compass gangs of poor down-trodden mortals, who were swooped down upon in their little hamlets far away and carried off? ${ }^{24}$

According to Legros' informants, the average Yeke raiding party was led by one or more mutwale (who were also frequently banangwa) designated and appointed by Msiri. Each 
mutwale commanded a bulungu, the basic Yeke military unit. This consisted of a core of about twenty gunmen, whose firearms were personally entrusted to them by Msiri, and a further group of more lightly armed fighters, numbering between sixty and one hundred. ${ }^{25}$ Depending on the nature of the particular expedition being prepared, several bulungu could operate together. In 1885, for instance, Capello and Ivens encountered a large Yeke war band near present-day Lubumbashi. On this occasion, the overall leader of the 'horde of brigands', the aforementioned Dikuku ('Licuco'), commanded 'about 400 men' equipped with 'firearms, arrows [and] spears'. ${ }^{26}$

\section{Insurgency}

How did Yeke militarism and violent forms of governance impact on the social landscape of Katanga? From a purely military point of view, the frequency of Yeke predatory raids and, to a lesser extent, full-blown wars of expansion and their reliance on firearms account for the spread and increasing use of fortifications in the region. Defences around settlements varied a great deal. The most elaborate were probably those surrounding permanent Arab-Swahili bases in the interior. For instance, Shimba's stockaded headquarters on Kilwa Island, Lake Mweru, which neither Yeke nor Congo Free State Forces ever managed to storm in the late 1880s and early $1890 \mathrm{~s},{ }^{27}$ included 'two bullet-proof blockhouses; [there was] no ditch but a two- or threemetre tall wooden rampart that could not be scaled. ${ }^{28}$ But basic fortifications consisting of a crenelated palisade and encircling ditch were to be found in virtually every Katangese village. ${ }^{29}$ These became especially effective when associated with such natural defences as caves and crags. Defensive complexes of this kind enabled a number of mountain communities to retain a degree of autonomy vis-à-vis the Yeke, ${ }^{30}$ and would prove difficult to overcome even for European-led forces. In June 1895, for example, chef de poste Brasseur had 'one man killed and three wounded' when he rushed the village of Kalera, on the eastern flank of the Mitumba Mountains. 'The natives', after 'defend[ing] themselves like devils', evacuated their village and retreated into a natural tunnel which Brasseur dared not enter 'for I would lose half of my soldiers there. [...]. There must be three or four exits to these tunnels, but no one besides the people of the village knows them.' 31 Three years later, Delvaux, one of Brasseur's successors in Katanga, came to identical conclusions when he took on another naturally-fortified settlement, Mukana's. There was - he argued - simply 'no hope of entering the cave' in which the defenders had sought shelter after pulling out of their village. ${ }^{32}$

Because of the wide distribution of fortifications, most military encounters in late nineteenth-century Katanga appear to have involved more or less prolonged sieges (though, at least in areas of limited visibility, ambushes must have been common as well). Reflecting the prejudices of his time and race - which construed African conflict as either exceptionally savage or, conversely, as exceptionally mild and cowardly ${ }^{33}$ - Brasseur was dismissive of this form of warfare and its lethality.

When the natives attack another village, they take position nearby - at a distance of a few hundred metres - build a stockade and remain there for months, killing whoever leaves the village and destroying the crops. 'They should make a sortie', you will say. They are niggers, you see, and then the attacker is always supposedly stronger than the defender. In short, if there are two or three fatalities on both sides, the affair was a hot one. ${ }^{34}$

In fact - regardless of whether assaults were truly 'unknown' to local Africans, another of Brasseur's questionable generalizations ${ }^{35}$ - sieges no doubt entailed significant hardship and constant vigilance. Coupled with the effects of the adoption of firearms in battle, they are likely to have resulted in enhanced military discipline for attackers and defenders alike. ${ }^{36}$ 
If these were the most common rules of battle at the height of Yeke power - if, that is, late nineteenth-century Katangese warfare was at least partly static - then the Sanga-led insurgency of 1891 was a game changer. Coinciding with the adoption of openly aggressive tactics by the victims of Yeke predation, it witnessed the emergence of a type of hit-and-run warfare which even coeval witnesses saw fit to describe under the rubric of 'guerrilla'. ${ }^{37}$ The key advantage of guerrilla methods, of course, is that they enable relatively small, but highly mobile, group of fighters to avoid set-piece battles while still striking at the heart of what, at least initially, constitutes a superior enemy in terms of both manpower and resources. Crucially, the Sanga met three essential preconditions for waging a successful insurgency: intimate knowledge of local terrain; widespread grassroots support; and a highly motivated leadership.

The Sanga were 'famous' hunters who had apparently enjoyed a 'monopoly over elephant hunting' before the inception of Garenganze. ${ }^{38}$ No doubt, the bushcraft skills accumulated during decades of intensive hunting stood them in good stead once they embarked on the path of armed resistance. ${ }^{39}$ Moreover, to the extent that tactics are shaped by terrain, guerrilla methods were well-suited to the topography of southern Katanga, a region characterised by the presence of such difficult and sparsely populated environments as mountain ranges and flatlands subject to seasonal flooding. The leaders of the rebellion were Sanga hereditary title-holders, whom the Yeke had subjugated but not replaced. While our sources do not permit a full discussion of their individual motivations and commitment to the insurgency, some tantalizing insights into the background and disposition of at least one rebel leader, Mulowanyama, are provided by Campbell. Mulowanyama - the PB missionary reminisced in the early 1920 s - was a 'veritable modern Nimrod' whose name, in fact, meant 'game wizard'. Having had 'his ears cropped off by order' of Msiri, his hatred for the latter 'and his tribe, the Ba-Yeke', was 'implacable' ${ }^{40}$ In this, Mulowanyama was far from alone, for 'all the Sanga' - if we are to believe Delcommune - hated the Yeke 'looters with a passion'. The mere mention of the name 'Yeke' - 'detested throughout Katanga' - was enough to 'inflame their eyes with rage'. ${ }^{41}$ This reservoir of popular resentment - itself the product of the divisiveness and exploitativeness of the late nineteenth-century warlord order - granted the insurgents the grassroots backing and protection that every successful guerrilla movement requires. And if further proof is needed of the popularity of the rebellion, it is provided by the rapidity with which it spread, drawing into its fold not only the bulk of the Sanga, but several non-Sanga communities as well.

The insurgency's spark, as is confirmed by several coeval sources, was the accidental murder of Masengo, a Sanga woman, and the subsequent refusal on Msiri's part to hand over the legal culprit - that is, the Yeke owner of the slave who had fired the accidental gunshot. ${ }^{42}$ But the fate of Masengo was a mere 'casus belli', behind which, as the eyewitness Crawford put it, lay 'deep, deep-seated grudges of long-standing against Msidi's tyranny' ${ }^{43}$ Building perhaps on the socially-sanctioned recourse of slighted parties, who became kapondo (assassins) to avenge an individual wrong, ${ }^{44}$ the Sanga, who had certainly managed to accumulate some muskets by the time of the rebellion, began a series of nightly attacks against Bunkeya and other centres of Yeke power. The first recorded action of the war took place during the night of 20-21 February 1891, when seven huts in Msiri's own section of Bunkeya, Nkulu, 'were maliciously set on fire and burnt to the ground' under the cover of darkness. Two women and a child were shot in another quarter of the capital, and one more casualty was recorded in Kankofu, the neighbouring village of Ntalasha ('Ndalasia'), Msiri's classificatory brother. ${ }^{45}$

The timing of the attack is interesting: January-February is the height of the rainy season in Katanga, and floods make movement, in general, and military manoeuvres, in particular, extremely problematic for anyone but the swiftest and most experienced of assailants. ${ }^{46}$ Far from slowing down the Sanga, rain conditions might have actually favoured 
them, for their forays increased in intensity and geographical extent in the aftermath of the first raid on Bunkeya. As early as 26 February, 'two or three houses were burned down [. . .] at different villages', and 'many of the Vasanda [sic]' were already said to have joined the rebellion. ${ }^{47}$ Between March and April, the Yeke settlements of both Dikuku ('Lukuku') and the more distant Mulenga ('Molenga') came under attack. ${ }^{48}$ An entire village belonging to the former was burnt down during the night and several people shot, 'four of whom died immediately'. ${ }^{49}$ By then, Msiri - whom the Sanga insurrection had reportedly left 'bewildered' and 'in a strange lethargic condition' ${ }^{50}$ - 'no longer [slept] unprotected, but ha[d] a large bodyguard sleeping around his house every night', ${ }^{51}$ while the inhabitants of Bunkeya's outlying quarters were being forced to seek shelter from 'the night raids of the Vasanga' in the central, fortified, areas of the capital, where they built a great many temporary accommodations. ${ }^{52}$

One of the obvious aims of the guerrillas was to generate panic among the inhabitants of Yeke settlements by asserting their ability to strike undetected at even the most closely guarded of targets. In this, they were successful, since by May feelings 'in and around the Capital' were running high, as residents felt unprotected by Msiri and 'liable to be shot down at any time. ${ }^{53}$ The contrast could not have been greater with the situation obtaining only a few years earlier, when the silence and safety of Bunkeya nights had impressed Arnot, prompting him to conclude that 'life and property [...] are safer here than in much-favoured England. 54 But Sanga attacks were not always random and clearly drew on preliminary intelligence. On occasions, they singled out specific members of the Yeke or Yekeized hierarchy, such as headman 'Muluwe', who had his 'omande' shell - a key symbol of Yekehood - removed from his body before being 'shot through the heart' in the early hours of 10 May. ${ }^{55}$ The fact that Muluwe's women and children escaped his burning village and sought refuge at the mission suggests that the seizing of prisoners (which in some cases might have amounted to the liberation of captives of the Yeke) was probably a frequent by-product of Sanga incursions, though the PB missionaries only make explicit mention of it once, in the context of an attack on a Yeke colony near chief Katanga in late May or early June. ${ }^{56}$ In this connection, it is probably relevant to note that, in 1895, Mulowanyama was still in the possession of 'a hundred or so women he had abducted from the Yeke' at an unspecified period in the past. ${ }^{57}$

Not the least innovative aspect of the insurgency was its economic dimension. Revealing a good grasp of the political economy of Msiri's warlord state, the Sanga resolved to pair their direct military actions with a policy of strangulation intended to disrupt the lines of communication between the heartland of Garenganze and the Ovimbundu plateau, thereby preventing Msiri from resupplying his military stock with new muskets and, especially, gunpowder, at a time in which his forces were also being tested by the Lunda of Kazembe, on the lower Luapula, and by Shimba, on Lake Mweru. By 'stopping and looting Msiri's caravans' at, or en route to, the Lualaba ferries, ${ }^{58}$ the Sanga achieved the twin objective of weakening and impoverishing Msiri while funding their own rebellion. This tactic proved highly effective in restricting freedom of movement in southern Katanga, as attested in the late spring by CFS official Paul Le Marinel, who discovered it was impossible to travel between Bunkeya and the headwaters of the Dikulwe, 'for the Sanga were blocking the routes'. ${ }^{59}$ Finding himself constrained by lack of gunpowder, Msiri could not reply decisively to the outbreak of the insurgency and was forced to postpone his counteroffensive for several months. ${ }^{60}$

By the end of May, 'many reports of murders by the Va-sanga' were reaching the PB missionaries, who also learnt that Msiri's own Sanga drummers had fled Bunkeya 'and joined their countrymen in the rebellion. ${ }^{61}$ Over the course of the same month, however, the Yeke supply situation registered a temporary improvement, thanks to the powder which Le Marinel eventually agreed to give Msiri and to the arrival of a well-stocked Angolan caravan which had managed to force the Lualaba blockade. ${ }^{62}$ Finally 'in a position to make a big muster of war parties', Msiri dispatched two separate military expeditions in the early summer of 1891 . While 
Dikuku went up the Lufira with a view to protecting the salt pans of Mwashya from attacks by the Sanga of Mutwila, another column, led by Msiri's son, Mukanda Bantu, took a southwesterly direction and confronted the enemy in the 'Va-Sanga stronghold' of Kalunkumia, the holder of the Mpande, the ancient paramount chiefly title of the Sanga. After much firing, Kalunkumia's 'Va-sanga were compelled to evacuate the town and flee south, in the direction of Ntenke's', who despite being a member of Msiri's original following and his representative among the copper-producing peoples of the upper Lufira River, had by then also joined the rebellion. ${ }^{63}$ 'No chase seems to have followed, and the war parties returned to the capital without striking any decisive blow. ${ }^{64}$

Despite this setback, the Sanga and their growing network of allies held out, while the internal situation of the besieged and isolated Garenganze continued to deteriorate. Not only had the 'war [...] reduced Msidi's ivory tribute this year to almost nothing', but ongoing Sanga forays also forced the inhabitants of Bunkeya not to "venture out far to the fields they were wont to cultivate' before the start of the insurgency and to limit themselves to 'tilling the poor stony soil' of the hill around which the Yeke capital had been built. ${ }^{65}$ This had the effect of accelerating the onset of a famine partly brought about by that year 'exceptionally dry condition. ${ }^{66}$ Famine and security concerns, in turn, led to population losses. By OctoberNovember, 'more than half' of Bunkeya's population had fled, ${ }^{67}$ 'the capital [had] quite a deserted look about it', ${ }^{68}$ and Msiri was once again short of powder. ${ }^{69}$ Dikuku, meanwhile, had failed to overcome Mutwila, ${ }^{70}$ while the Lomotwa of the Kundelungu Range, who 'abhorred' their Yeke mwanangwa, Kifuntwe ('Kifumtiè'), had thrown their lot in with the rebels. ${ }^{71}$ Running out of options, Msiri sought unsuccessfully to induce both Delcommune and the CFS officials in Lofoi - the station inaugurated by Le Marinel late in May 1891 - to fight the insurgents on his behalf, and might have even contemplated the possibility of shifting the location of his capital. ${ }^{72}$ By mid-December, when William Stairs and his 300 men (200 of whom equipped with modern breech-loaders) made their entry into Bunkeya, the famine was 'appalling' and the central symbol of Yeke power a pale shadow of its former self. ${ }^{73}$ Msiri's father-in-law, the Angolan trader Coïmbra, told Stairs that the ten quarters into which Bunkeya had been subdivided a mere three years earlier were now reduced to one and that the hills to the south-west of the town, once 'dotted with flourishing villages', were now almost entirely depopulated. ${ }^{74}$

Lack of gunpowder and the Sanga blockade remained Msiri's most pressing concerns to the very end. One last Yeke sortie, against Mulowanyama, took place between November and December, in retaliation for an earlier attack on a party of eastbound traders at the Lualaba ferry. At the time, the missionary Thompson was being detained by Mulowanyama in the village of his Bena Mitumba ally, Mwenda Mukoshi. ${ }^{75}$ Stating that 'the Va-Sanga will no longer by the slaves of Msidi', Mulowanyama 'refused to allow our caravan or any other to come to Msidi's' ${ }^{76}$ Eventually, the rebel leader - who appreciated the neutral stance taken by the PB and their unwillingness to assist Msiri in communicating with 'traders to bring powder to him' - was persuaded to give Thompson permission to proceed to Bunkeya, but also insisted that the members of his caravan who carried powder stay put until they had exchanged all of it locally. ${ }^{77}$ On 2 December, while negotiations were still ongoing, Thompson witnessed Mukanda Bantu's ambush. 'I saw men and women returning from the fields in hot haste, and making for their villages beside our camp. Immediately I heard the beat of a war drum, and a number of shots were discharged in the bush, about 250 yards from our camp. [...]. Msidi's party caught about eleven of the Va-sanga in the fields and forthwith decapitated them, as a quid pro quo, I suppose, for those killed at the ford by the Va-sanga.' Thompson's intervention apparently prevented further bloodshed and convinced the Yeke aggressors to decamp without having succeeded in lifting the blockade. ${ }^{78}$ Even the Yeke military no longer believed in victory. 


\section{Counterinsurgency}

Stairs clashed with Msiri over his determination to force the CFS flag on the Yeke warlord and refusal to furnish him with the gunpowder he craved. ${ }^{79}$ Tension escalated between 16 and 20 December, the day in which Msiri was shot dead by Belgian officer Bodson and his escort. ${ }^{80}$ The assassination of Msiri further compounded the plight of the Yeke and their new leader, Mukanda Bantu, who were now faced with the very real prospect of complete annihilation. Mulowanyama, for one, is said to have appealed to Stairs to 'exterminate' all of Msiri's people before his departure. ${ }^{81}$ In some cases, these aspirations were being into practice. In June 1892, for instance, a group of Lomotwa assassinated their former mwanangwa, Kifuntwe ('Cifuntwi') - an episode which Crawford read as a demonstration of the fact that 'they who once were the oppressors are now in a degree the oppressed. ${ }^{82}$ 'A short time' afterwards, ten followers of Mokembe, Msiri's brother, were murdered by the 'Ve na Mitumba' (Bena Mitumba, or Sanga of the Mitumba Mountains) "when on a journey of peaceable intent. ${ }^{83}$

The Yeke's decision to abandon Bunkeya and regroup in and around Lutipisha, to the immediate south of the newly-founded CFS post of Lofoi, in late 1892-early 1893 was a clear sign of the precariousness of their position. ${ }^{84}$ In this tense context, Legat, the officer in charge of Lofoi in 1891-1893, and his companion Verdick followed a very cautious course of action, doing little more than (literally) holding the fort with the thirty-odd regular Force Publique soldiers at their disposal. Despite having been enjoined by his superiors to make Lofoi selfsupporting and to gather the greatest possible amount of ivory, the most valuable Katangese commodity on the world's market in the 1890 s, Legat - as he would openly admit to his successor before leaving the region - never felt strong enough to force the hand of the Sanga and other leaders who kept harrying the Yeke, paid no taxes and kept well clear of Lofoi. ${ }^{85}$ This wait-and-see policy changed with a vengeance from the autumn of 1893, when Lofoi was taken over by a relief column commanded by Lieutenant Clément Brasseur, to whom reference has already been made above.

Determined to maximize the State's - and therefore his own ${ }^{86}$ - revenue at all costs, Brasseur inaugurated a reign of terror that made a vivid impression on both the PB missionaries, who would eventually denounce his doings, and local Africans, by whom he was nicknamed Nkulukulu. The Nkulukulu - Judge Jenniges explained a few years after Brasseur's death - was a bird 'whose inner wings are bloody red. Now, the natives say, Mr. Brasseur was only happy when he had blood up to his armpits. Then he looked like the bird in question'. ${ }^{87}$ Brasseur's extractive methods were especially crude. Bespeaking of an earlier warlord order, they revolved around the deployment of so-called 'sentries' - unsupervised regular soldiers stationed in prominent villages and entrusted with the task of collecting "“all the ivory in the country" 'by hook or crook ${ }^{88}$ - and the staging of large-scale military expeditions intended both to plunder the surroundings of Lofoi and to impress upon local leaders the need to comply with instructions relating to taxation in kind and labour.

For all of his rapaciousness, racism and penchant for violence, Brasseur, left to his own devises and those of his few regular soldiers, would never have secured what he termed 'the complete subjugation of the country'. ${ }^{89}$ Thus, in the furtherance of this objective, he - like countless empire-builders before and after him - set out to exploit local conflicts and manpower, ${ }^{90}$ and turned to the beleaguered Yeke. Brasseur himself explained that popular 'hatred against the Yeke suit[ed him] perfectly.' 91 'Having raided, killed and looted overmuch', the 'remnants' of the Yeke 'were now pitted against every other race'. They were as a result 'devoted to the whites'. ${ }^{92}$ But Mukanda Bantu's surviving followers, of course, had a pressing agenda of their own. By reinventing themselves into a rapid deployment, auxiliary force at the service of Lofoi, they aspired to rebuild that regional hegemony which the Sanga rebellion and 
the death of Msiri were threatening fully to eradicate. The alliance with the CFS, in other words, offered the Yeke the chance to roll back the years and check the assertiveness of the Sanga and other former subjects. In the process, the Yeke military played a critical role in shaping from below a violent counterinsurgency campaign which the Europeans coordinated and benefitted from, but whose ultimate meanings and direction they did not always control or even fully understand.

Beginning in 1894, Mukanda Bantu and his gunmen participated in all of the major expeditions carried out by Brasseur and/or his two deputies. In July of that year, about onehundred Yeke joined Brasseur's foray against Mutwila, guilty of preventing chef Mwashya from delivering his quota of salt to Lofoi. ${ }^{93}$ Mutwila - as we know - had stood up to Dikuku in the summer of 1891 and was regarded by the Yeke as a serious menace and one of the main causes of 'the ruin of Msiri'. ${ }^{94}$ The fortified villages of Mutwila and his brother were stormed by the CFS-Yeke force. Numerous children and women were killed during what the missionary Campbell called the 'great slaughter' that followed the attack. ${ }^{95}$ Brasseur, his soldiers and auxiliaries returned home with, inter alia, sixty female prisoners and fourteen ivory tusks. Even though, on this occasion, Brasseur was unimpressed by the performance of his Yeke allies who had apparently behaved cowardly during the assault but as a 'pack of famished wolves scrambling for a corpse' in its aftermath ${ }^{96}$ - Mukanda Bantu was naturally delighted at the demise of the old opponent, treating Brasseur to a drinking party in Lutipisha and then escorting him back to Lofoi with a following of 'at least 200 ' people. $^{97}$

But Brasseur's violence was not always indiscriminate, and his actions suggest that he understood that most basic of counterinsurgency tactics: the sowing of divisions among opponents by means of both threats and inducements. ${ }^{98} \mathrm{He}$, in particular, went out of his way to prevent his Yeke auxiliaries from attacking Kalunkumia and Mulowanyama's bases during a joint expedition to Sanga and Bena Mitumba territory in the spring of 1895 . In the case of the former, Brasseur's conciliatory policy initially worked. Persuaded to return to his capital, which he had fled as the military column approached, Kalunkumia accepted to house one of Lofoi's outstations and became a regular ivory contributor until the death of Brasseur. ${ }^{99}$ Mulowanyama, on the contrary, sought refuge deep in the Mitumba Mountains, whence - as will be seen below - he would spend the last few years of his adventurous life scheming against the new dispensation and Yeke-CFS rule.

Less accommodating or strategically important leaders, on the other hand, could expect little mercy. Thus, over the course of the same 1895 tour, Brasseur, his force Publique soldiers and Mukanda Bantu's warriors (probably numbering between 100 and 200) took the side of local Yeke grandees against autochthonous claimants in the succession dispute that followed the death of one of Msiri's former subordinates, Kalala Ngombe. ${ }^{100}$ Both the aforementioned attack on Kalera's and the destruction of Ngonga's settlement late in May are to be set in this context. ${ }^{101}$ One year later, the bulk of the porters and irregulars who accompanied Brasseur's on his longest tour yet was still made up of Yeke. Targeting another historical enemy of Msiri, the Luba-speakers of the Upemba Depression and the Luvua River, this expedition - the most murderous of Brasseur's Katangese journeys - did not witness the direct participation of Mukanda Bantu, whose place was taken by mwanangwa Kasadi, attracted to the upper Lualaba by the prospect of capturing female slaves galore. ${ }^{102}$

Apart from the direct casualties of massacres - along the Lualaba and Luvua rivers alone, Brasseur's mixed forces were responsible for a minimum of 75 deaths between late June and early August $1896^{103}$ - the human costs of these 'pacification campaigns' were probably magnified by the processes of adaptation and mutual borrowing which underlay them. Mukanda Bantu showed no compunction about imitating Brasseur's textbook infantry tactics. ${ }^{104}$ But influence did not flow in one direction only, and the pre-colonial military knowhow of Yeke militias could not but have an impact on Brasseur and his Force Publique. Both 
the practice of living off the land while on campaign and the punitive burning of villages and crops ('a general custom with the Vayeke', according to the missionary Swan ${ }^{105}$ ) enhanced the lethality of the Yeke-Force Publique counterinsurgency campaign and the sufferings it inflicted on non-combatants. Equally important in psychological terms was the mutilation of the bodies of dead enemies, a practice stemming both from Brasseur's desire to monitor cartridge usage and Yeke beliefs in the need to purify the heads of slain enemies. ${ }^{106}$ The large-scale taking of prisoners, meanwhile, served both to increase Lofoi's servile workforce and to replenish Mukanda Bantu and the other Yeke chiefs' depleted slave stocks. Early in 1892, in the immediate aftermath of Msiri's death, Mukanda Bantu had cut a powerless figure, surrounded by a mere 'handful of people' and camping among the ruins of Bunkeya, his father's all but deserted former capital. ${ }^{107}$ By Jan. 1896, however, Lutipisha was being described as a 'great seething town' harbouring (in Brasseur's conservative estimate) some 3,000 residents. ${ }^{108}$ The figure of 5,000 was given in June 1897 by Campbell, ${ }^{109}$ who, however, would later downsize his estimate to 3,000. Of these only one fifth were reported to be men, ${ }^{110}$ a skewed demographic composition which suggests that the economic role of female slaves was no less important in Lutipisha than it had been in Bunkeya.

Despite - or perhaps because of - Brasseur and Mukanda Bantu's efforts, the enemies of the Yeke kept up a low-intensity guerrilla war throughout the mid-1890s. Now that the nerve centres of the new dispensation - Lofoi and Lutipisha - had been strengthened, the insurgents' forays targeted more remote areas, primarily the Mitumba Mountains, where the inhabitants of Yeke settlements were reportedly being fired upon when going into the woods or the fields in August $1895 .{ }^{111}$ It was also in the Mitumbas and, specifically, the Kiamakele network of natural tunnels that Mulowanyana sought shelter after he abandoned his less easily defensible village in October of the same year. ${ }^{112}$ Thereafter, Mulowanyama struck an alliance with the then Kazembe of the Lualaba, an important title-holder who controlled a ferry across the Lualaba and whom Mulowanyama appears to have turned against Lofoi in the early part of $1896 .{ }^{113}$

Such worrying developments amongst the Bena Mitumba and along the Lualaba prompted Brasseur to send Mukanda Bantu and a 200-man-strong war party drawn from at least fifty separate villages on a solo expedition to the areas in question. ${ }^{114}$ Granted complete freedom of action during the journey, Mukanda Bantu was expected to secure the Lualaba crossing, attack a number of unyielding Sanga and Bena Mitumba chiefs and bring back as much ivory and as many prisoners as possible. ${ }^{115}$ Mukanda Bantu - who now reportedly insisted on being called Nzige (locust), because "II have many people, and when the white man sends me somewhere, I raze everything to the ground, like the locusts do""116 - and his paternal uncle Mokembe did not disappoint expectations. Not only did they replace the Kazembe of the Lualaba with a man of their choice, kill chief Kasangula and burn down the village and crops of Mwenda Mukoshi. ${ }^{117}$ But by the time they returned to Lofoi in January 1897, they had also accumulated 'twenty-odd women, some boys and 26 tusks', as well as 'a great deal of plunder from raided villages and the skulls of the people killed during the journey (31) in baskets.' 118 Since such raid was an almost exact replica of one of Msiri's rafles, it is perhaps not surprising that, at least according to Campbell, "'one of the male prisoners [...] was sacrificed at the grave of old Msiri unknown to the State." 119

For all its immediate effectiveness, Mukanda Bantu's counterinsurgency expedition created more problems than it solved for Brasseur. By as early as March 1897, the chiefs targeted by Mukanda Bantu had regrouped and declared war on the Yeke village of Kalala Ngombe. ${ }^{120}$ At about the same time, a Sanga force of which Mulowanyana might have been part seized the village of the Yeke-backed Kazembe of the Lualaba and replaced the latter with a competitor. ${ }^{121}$ By April, 'exception made for five or six villages, the Bena Mitumba [had] risen up almost everywhere', ${ }^{122}$ attacking isolated Yeke villages in a repeat of the hit-and-run tactics pioneered by their Sanga peers at the beginning of the decade. In the summer, 'hardly a 
month' went by without 'one chief or another' complaining to Brasseur that 'his village ha[d] been burned down and his people killed. ${ }^{123}$ Eventually, Brasseur came to the conclusion that the rebellion that was engulfing the Mitumbas - one in which he suspected the Sanga paramount, Kalunkumia, of being implicated ${ }^{124}$ - necessitated the dispatching of another punitive expedition by Mukanda Bantu. This was tentatively scheduled for after his own return from the Lualaba, where he travelled in August 1897 to thwart the Sanga-supported Kazembe of the Lualaba and officially re-install the Yeke's candidate. ${ }^{125}$

Brasseur's plans for reducing the ongoing insurgency were brought to an abrupt end by his death in November 1897, when he was fatally wounded during the siege of the fortified settlement of the coastal trader Kiwala, on the upper Luapula River. Despite missionary expectations to the effect that his demise might bring about 'a more humane state of affairs in Katanga' ${ }^{126}$ the Yeke-Force Publique counterinsurgency effort proceeded unabated, reaching its violent climax in 1899. In 1898 - as Verdick, the new chef de poste, discovered during a tour of the south-east - Kalunkumia, 'disgruntled' by 'the protection afforded to the Yeke' by Lofoi, ${ }^{127}$ threw moderation to the wind: followed by many of his subjects, he abandoned his village on the upper Dikulwe and settled in Kiamakele, near Mulowanyama's. ${ }^{128}$ During the previous two years, Mulowanyama - whose local 'prestige and influence' were 'considerable' - had reportedly 'harassed' some of the outposts of Lofoi and committed 'more than fifty murders'. ${ }^{129} \mathrm{He}$ was also rumoured to be planning an attack on the missionary George during his upcoming return journey from Angola and to be still bent on controlling the Lualaba ferry with a view to monopolizing communications with Ovimbundu slave and gun traders. ${ }^{130}$

Early in 1899, following some renewed Sanga and Bena Mitumba threats against the Kazembe of the Lualaba and the nearby Yeke village of Nguba, Verdick, accompanied by one hundred Force Publique soldiers, 'about fifty' of Mukanda Bantu's irregulars and a $47 \mathrm{~mm}$ Nordenfelt cannon, marched against the rebels' headquarters. ${ }^{131}$ Mulowanyama's village was bombarded on 20 March. After a heavy exchange of fire - during which a Belgian sublieutenant, Fromont, as well as three regular soldiers and two Yeke auxiliaries were killed the defenders withdrew into their tunnels, which the attackers did not penetrate but sealed from the outside by means of large boulders. ${ }^{132}$ Despite Verdick's and, later, Delvaux's attempts to negotiate their surrender - and even though Kalunkumia and several other Sanga and Bena Mitumba chiefs tendered their final submission in the weeks that followed the assault ${ }^{133}$ Mulowanyama and his remaining supporters held out in their redoubt for more than three months. Having run out of food supplies, the survivors - a paltry group of two men, five women and six children - gave up on 25 June; by that point, most of the defenders, including the irrepressible Mulowanyama, had succumbed. Once, after several days' work, he negotiated a way into the main tunnel, part of which had collapsed, the Belgian Delvaux discovered to his 'horror' that it was 'nothing but an immense graveyard'. He counted 178 asphyxiated and decomposing corpses and 142 guns. ${ }^{134}$ Before leaving Kiamakele, Delvaux set fire to the place. 'The tunnels caved in one by one, and Mulowanyama's grave was shut away for ever.' ${ }^{135}$ The Yeke-Force Publique counterinsurgency had carried the day.

\section{Conclusion}

During the violent 1890s, Yeke policies were dominated by the imperatives of surviving the consequences of the Sanga rebellion and of reconstituting their hegemony in tandem with the newly arrived forces of the Congo Free State. Intersecting with European motives, Mukanda Bantu's strategy proved wonderfully effective: not only did the Yeke survive as a corporate group against considerable odds, but they did so as the dominant African ethnicity in colonial southern Katanga. The real victims were those communities who had rebelled against Yeke predation, had briefly regarded the incoming whites as possible saviours, ${ }^{136}$ and then found 
themselves at the receiving end of a nasty counterinsurgency campaign jointly carried out by the same European-led forces and their former Yeke exploiters.

The Sanga rebellion was defeated - and several decades of colonial social engineering and politico-economic change would prove necessary to heal old wounds. Eventually, as Yeke, Sanga and other local ethnicities found a new unity under the banner of an invented Katangese 'autochthony' ${ }^{137}$ memory of the Sanga insurgency faded into the background (a process to which the very gruesomeness of the rebellion's ending might have contributed). But though unsuccessful and now largely forgotten, ${ }^{138}$ the Sanga rebellion still has some important lessons to teach us. First, the central role played by Yeke forces in the 'pacification' of Katanga implies that historians who stress the innovative character of the 'small wars' of nineteenth-century imperialism - be it on account of the new technologies they utilized or the unprecedented strategic objectives which underpinned them - have invariably tended to overplay their hand. ${ }^{139}$ This is not only because - as Walter has recently argued - the imperial wars of the late nineteenth century display a 'striking family resemblance' with all the violent conflicts that have accompanied the territorial expansion of Europe from the sixteenth century. ${ }^{140}$ More important is the fact that what southern Katanga (and much of the rest of central Africa as well) witnessed in the 1890s was a process of mutual borrowing and hybridization in which African military practices and even political aims were far from being ancillary to European ones. In fact - as Macola has argued more at length elsewhere ${ }^{141}$ - 'creolization' processes went beyond the military sphere and invested the totality of the early colonial dispensation in the Congo basin, which was Africanized, not only through the armed personnel on which it drew, but also in the institutions and practices of rule it adopted and in the symbolism of power it was charged with. In sum, when it is examined from the ground up and from the perspective of the defeated, the conquest of Katanga looks much more like the continuation of an earlier warlord order in disguise than like the external imposition of 'modern' military and political models.

More generally, this well-documented instance of rebellion and counterinsurgency before and during the colonial occupation of Katanga forcefully reminds us that African military history does not begin with the arrival of European forces. Military dynamics were no less vibrant and subject to change in the pre-colonial era than in later periods. And a full grasp of even the most modern of central African conflicts is destined to remain elusive unless these same conflicts are placed in a longue-durée perspective - one that must at least make room for the revolutionary transformations experienced by the sub-continent in the nineteenth century and the enhanced militarism and predatory style of politics that they brought into being.

Giacomo Macola is Reader in African History, University of Kent, and Research Fellow, International Studies Group, University of the Free State. His latest book is The Gun in Central Africa: A History of Technology and Politics (Athens, $\mathrm{OH}, 2016)$. He is also the editor of The Colonial Occupation of Katanga: The Personal Correspondence of Clément Brasseur, 18931897 (Oxford, 2018).

Jack Hogan completed his PhD at the University of Kent in 2014 ('The Ends of Slavery in Barotseland, Western Zambia'). He is currently working as an LSE Teaching Fellow.

\footnotetext{
${ }^{1}$ Reid, War in Pre-Colonial Eastern Africa, 3.

${ }^{2}$ For more on this point, see Thornton, 'Placing the Military in African History'.
} 


\footnotetext{
${ }^{3}$ Macola has recently edited and co-translated into English seventeen of Brasseur's 'Katangese' letters to his brother Désiré: Macola (ed.), The Colonial Occupation of Katanga (henceforth TCOK). All future references to Brasseur's letters come from this edition. A full description of the original collection - housed in the historical archives of the Africa Museum, Tervuren, RG 768/81.15 - can be found in Macola, 'Introduction'.

4 The classic statement is Terence Ranger's two-part article: 'Connexions between "Primary Resistance Movements" and Modern Mass Nationalism'. The long life of this whiggish interpretation is attested, inter alia, by Nzongola-Ntalaja, The Congo from Leopold to Kabila, chapters 1-2.

5 See, e.g., Vandervort, Wars of Imperial Conquest in Africa. A more accomplished and ambitious work of synthesis is Walter, Colonial Violence.

${ }^{6}$ For a critique of the 'presentism' of much recent Africanist historiography, see Reid, 'Past and Presentism'.

7 The timing of Msiri's arrival in southern Katanga is discussed by Legros, Chasseurs d'ivoire, 28-29.

${ }^{8}$ The incorporation of the central African interior into the Indian Ocean and Atlantic trading frontiers has long formed a subject of scholarly enquiry. Recent overviews of the relevant literature are Gordon, 'The Abolition of the Slave Trade', and Macola, The Gun in Central Africa, chapter 1.

${ }^{9}$ Arnot, Garenganze, 233; Legros, Chasseurs d'ivoire, 119.

10 'Lettre de Mwenda II Mukanda Bantu', 41, 43; Legros, Chasseurs d'ivoire, 121.

${ }^{11}$ One of the principal Lualaba crossing points was located to the immediate south of Lake Kajibajiba, among peripheral Luba peoples subjugated by the Yeke in the early 1870s. Another one was to be found further upstream, in the area of the Kazembe of the Lualaba. See, e.g., Le Marinel, Carnets de route, 155-156, 159, and Arnot, Bihé and Garenganze, 56-57.

${ }^{12}$ See, e.g., Arnot's fascinated description in Garenganze, 235.

${ }^{13}$ Reichard, 'Herr Paul Reichard', 119.

${ }^{14}$ Victor Giraud was told of Msiri's military might while among the Aushi of the upper Luapula in 1883; Les lacs de l'Afrique équatoriale, 318-319.

${ }^{15}$ Legros, Chasseurs d'ivoire, 80-85.

${ }^{16}$ Ibid., 110-111.

${ }^{17}$ Delcommune, Vingt années, vol. 2, 329.

18 D. Crawford, 'Dec. 1891', in Echoes of Service (henceforth ES), no. 273 (Nov. 1892), 257.

${ }^{19}$ C.A. Swan, 14 Dec. 1889, in ES, no. 230 (Jan. 1891), 25.

${ }^{20}$ F.S. Arnot, 11 Aug. 1886, in ES, no. 184 (April 1887), 59-60.

${ }^{21}$ Arnot, Garenganze, 243.

${ }^{22}$ Ibid., 194.

${ }^{23}$ Ibid.

${ }^{24}$ D. Crawford, 'Dec. 1891', in ES, no. 273 (Nov. 1892), 258.

${ }^{25}$ Legos, Chasseurs d'ivoire, 73-74.

${ }^{26}$ Capello and Ivens, De Angola á contra-costa, vol. 2, 169, 173.

${ }^{27}$ For more details, see Macola, The Kingdom of Kazembe, 155-159, 171-172.

${ }^{28}$ Macola, TCOK, 4.

${ }^{29}$ Ibid., $35,56$.

${ }^{30}$ Ibid., 33; Arnot, Garenganze, 198n.

${ }^{31}$ Macola, TCOK, 61.

${ }^{32}$ Delvaux, L'occupation du Katanga, 70.

${ }^{33}$ Smith, Warfare and Diplomacy, 50. See also Reid, 'Revisiting Primitive War', 1-2.

${ }^{34}$ Macola, TCOK, 54. For a consistent, though less stridently formulated, view, see C.A. Swan, 23 Jan. 1888, in ES, no. 202 (Oct. 1888), 317

${ }^{35}$ Macola, TCOK, 512.

${ }^{36}$ Iliffe, A Modern History of Tanganyika, 52.

${ }^{37}$ D. Crawford, 18 May 1891, ES, no. 252 (Dec. 1891), 299; Stairs, 'De Zanzibar au Katanga', 183.

${ }^{38}$ Macola, TCOK, 32; Campbell, In the Heart of Bantuland, 264.

${ }^{39}$ Here, our observations echo Storey, Guns, Race and Power, 78.

${ }^{40}$ Campbell, In the Heart of Bantuland, 26. See also Stairs, 'De Zanzibar au Katanga', 191.

${ }^{41}$ Delcommune, Vingt années, vol. 2, 314-315.

${ }^{42}$ See, e.g., C.A. Swan, 10, 21, 26 and 28 Feb. and 1 March 1890, in ES, no. 251 (Dec. 1891), 288-289; and 'Lettre de Mwenda II Mukanda Bantu', 47, 49, 51.

${ }^{43}$ D. Crawford, 'Dec. 1891', in ES, no. 273 (Nov. 1892), 258.

${ }^{44}$ C.A. Swan, 21 Feb. 1891, in ES, no. 251 (Dec. 1891), 288; Jenniges, Dictionnaire français-kiluba, 17.

${ }^{45}$ C.A. Swan, 21 Feb. 1891, in ES, no. 251 (Dec. 1891), 288; Legros, Chasseurs d'ivoire, 84.

${ }^{46}$ See, e.g., Macola, TCOK, 145.

${ }^{47}$ C.A. Swan, 26 Feb. 1891, in ES, no. 251 (Dec. 1891), 289.
} 
${ }^{48}$ C. A. Swan, 20 March 1891, in ES, no. 251 (Dec. 1891), 290; C.A. Swan, 22 April 1891, in ES, no. 253 (Jan. 1892), 9.

${ }^{49}$ C.A. Swan, 20 March 1891, in ES, no. 251 (Dec. 1891), 290; 'Lettre de Mwenda II Mukanda Bantu', 51.

${ }^{50}$ D. Crawford, 18 May 1891, ES, no. 252 (Dec. 1891), 299; D. Crawford, 'Dec. 1891', in ES, no. 273 (Nov. 1892), 257.

${ }^{51}$ C.A. Swan, 20 March 1891, in ES, no. 251 (Dec. 1891), 290.

${ }^{52}$ C. A. Swan, 30 March 1891, in ES, no. 251 (Dec. 1891), 291; Le Marinel, Carnets de route, 201.

${ }^{53}$ D. Crawford, 18 May 1891, ES, no. 252 (Dec. 1891), 299.

${ }^{54}$ F.S. Arnot, 11 Aug. 1886, in ES, no. 184 (April 1887), 60.

${ }^{55}$ C.A. Swan, 10 May 1891, in ES, no. 253 (Jan. 1892), 10; Le Marinel, Carnets de route, 194. On the 'omande' (mpande), see Arnot, Garenganze, 234.

${ }^{56}$ C.A. Swan, 5 June 1891, in ES, no. 253 (Jan. 1892), 11.

${ }^{57}$ Macola, $T C O K, 64$.

${ }^{58}$ Macola, TCOK, 32. See n. 11.

${ }^{59}$ Le Marinel, Carnets de route, 202.

${ }^{60}$ D. Crawford, 'Dec. 1891', in $E S$, no. 273 (Nov. 1892), 257.

${ }^{61}$ C.A. Swan, 24 May 1891, in ES, 253 (Jan. 1892), 10.

${ }^{62}$ Le Marinel, Carnets de route, 190-191.

${ }^{63}$ D. Crawford, 'Dec. 1891', in ES, no. 273 (Nov. 1892), 257. For information on Ntenke, see Delcommune, Vingt années, vol. 2, 277-278. See also 'Lettre de Mwenda II Mukanda Bantu', 51.

${ }^{64}$ D. Crawford, 'Dec. 1891', in ES, no. 273 (Nov. 1892), 257.

${ }^{65} \mathrm{Ibid}$. See also Arnot, Bihé and Garenganze, 112.

${ }^{66}$ Delcommune, Vingt années, vol. 2, 249. See also Le Marinel, Carnets de route, 204.

${ }^{67}$ A. Legat to A. Delcommune, Lofoi, 13 Oct. 1891, in Delcommune, Vingt années, vol. 2, 272.

${ }^{68}$ D. Crawford, 'Dec. 1891', in ES, no. 273 (Nov. 1892), 257.

${ }^{69}$ Briart, Aux sources du fleuve Congo, 177, 179.

${ }^{70}$ Delcommune, Vingt années, vol. 2, 274, 295, 298.

${ }^{71}$ Ibid., vol. 2, 243, 296-297.

${ }^{72}$ Ibid., vol. 2, 260, 276, 291; Legat to Delcommune, 13 Oct. 1891, in ibid., 272; Stairs, 'De Zanzibar au Katanga', 183.

${ }^{73}$ Stairs, 'De Zanzibar au Katanga', 191.

${ }^{74}$ Stairs, 'De Zanzibar au Katanga', 197.

75 'Lettre de Mwenda II Mukanda Bantu', p. 53.

${ }^{76}$ Arnot, Bihé and Garenganze, 111; D. Crawford, 'Dec. 1891', in ES, no. 273 (Nov. 1892), 259

${ }^{77}$ Arnot, Bihé and Garenganze, 111.

${ }^{78}$ Ibid., 111-112.

${ }^{79}$ Stairs, 'De Zanzibar au Katanga', 191, 198; D. Crawford, 'Dec. 1891', in ES, no. 273 (Nov. 1892), 260-261.

${ }^{80}$ Stairs, 'De Zanzibar au Katanga', 199. Bodson himself was wounded by Msiri's gunmen and died shortly thereafter.

${ }^{81}$ Mwenda Munongo, 'Chants historiques des Bayeke', 64.

${ }^{82}$ D. Crawford, 25 June 1892, in ES, no. 281 (March 1893), 56-57.

${ }^{83}$ H.B. Thompson, 2 March 1893, in ES, no. 296 (Oct. 1893), 238.

${ }^{84}$ Ibid.; D. Crawford, 12 Feb. 1893, in ES, no. 297 (Nov. 1893), 251.

${ }^{85}$ Macola, TCOK, 3, 5, 382.

${ }^{86}$ The payment of premiums on the amount of produce that territorial officials were able to siphon out of their respective regions was a key means through which the CFS's central administration sought to encourage extractive activities in Leopold's colony. See, e.g., Stengers and Vansina, 'King Leopold's Congo', 339.

${ }^{87}$ J. Jenniges to Public Prosecutor, Lukafu, 1 March '1903' [sic, but 1905], Papiers L. Guebels, Africa Museum, Tervuren, RG 917.

${ }^{88}$ D. Campbell to H.R. Fox Bourne, Johnston Falls, 14 May 1904, in Morel, King Leopold's Rule, 460. See also D. Campbell, 7 May 1895, ES, no. 345 (Nov. 1895), 268, and D. Crawford, 1 Sept. 1895, ES, no. 351 (Feb. 1896), 45-46.

${ }^{89}$ Macola, TCOK, p. 26. A brief discussion of Brasseur's personality and worldview is to be found in Macola, 'Introduction', xx-xxii.

${ }^{90}$ Walter, Colonial Violence, 96.

${ }^{91}$ Macola, TCOK, p. 60.

92 Ibid., 6-7.

${ }^{93}$ Ibid., 14.

${ }^{94}$ Ibid., 16.

${ }^{95}$ D. Campbell, 2 May 1897, in ES, no. 397 (Jan. 1898), 13. 


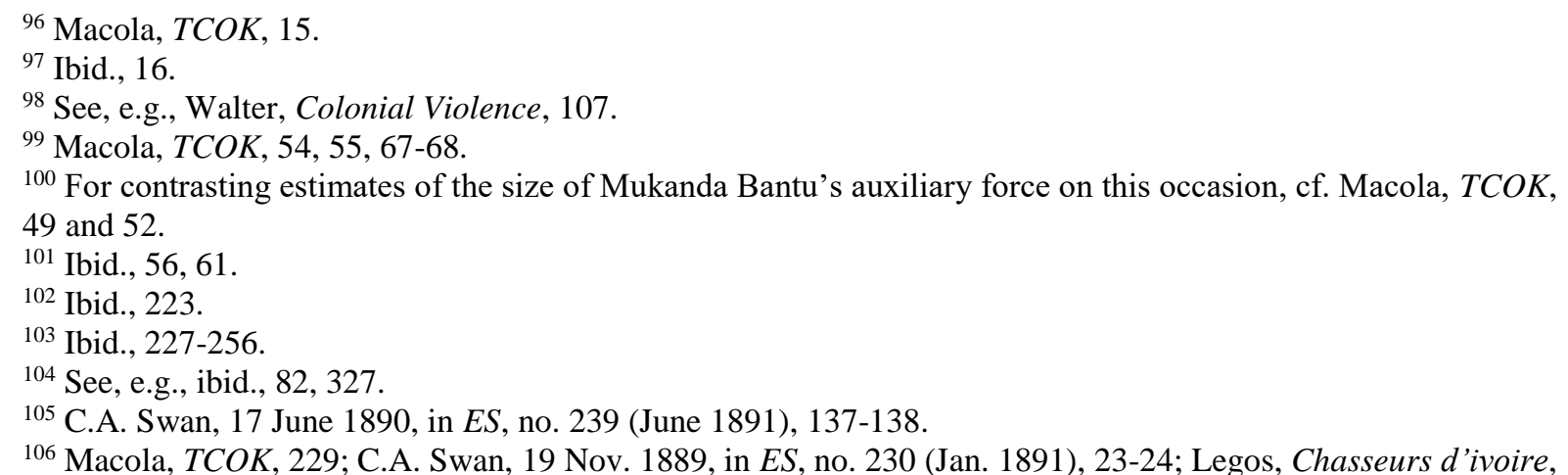

74-75.

${ }^{107}$ D. Crawford, 24 Feb. 1892, in ES, no. 274 (Nov. 1892), 269.

${ }^{108}$ D. Crawford, 5 Jan. 1896, in ES, no. 364 (Aug. 1896), 250; Macola, TCOK, 35.

109 D. Campbell, 6 June 1897, in ES, no. 394 (Nov. 1897), 345.

${ }^{110}$ Campbell to Fox-Bourne, in Morel, King Leopold's Rule, 460.

111 Macola, TCOK, 108.

112 Ibid., 123. For a description of a section of these tunnels, see ibid., 465, and Arnot, Garenganze, 198.

${ }_{113}$ Macola, TCOK, 145, 160, 195.

114 Ibid., 294, 295.

115 Ibid., 294.

116 Ibid., 326.

117 Ibid., 327, 359.

${ }^{118}$ Ibid., 358.

${ }^{119}$ Campbell to Fox-Bourne, in Morel, King Leopold's Rule, 456.

${ }^{120}$ Macola, TCOK, 375.

${ }^{121}$ Ibid., 390, 403, 460, 461-462, 470.

122 Ibid., 394.

123 Ibid., 448.

124 Ibid., 460-461.

125 Ibid., 451, 471.

${ }^{126}$ W. George, 3 Jan. 1898, in Echoes of Service, no. 409 (July 1898), 204

${ }^{127}$ Verdick, Les premiers jours, 114.

${ }^{128}$ Ibid., 115.

${ }^{129}$ Delvaux, L'occupation du Katanga, 74.

${ }^{130}$ J.W. M'Lachlan, 23 April 1899, ES, 438 (Sept. 1899).

${ }^{131}$ Verdick, Les premiers jours, 130-131.

132 Ibid., 137, 139.

${ }^{133}$ Ibid., 141-143; Delvaux, L'occupation du Katanga, 76.

${ }^{134}$ Delvaux, L'occupation du Katanga, 76. See also W. George, 12 Aug. 1899, ES, no. 448 (Feb. 1900), 57

135 Delvaux, L'occupation du Katanga, 76.

${ }^{136}$ W.G. Stairs to D. Crawford, [25 Dec. 1891], in D. Crawford, 'Dec. 1891', in ES, no. 273 (Nov. 1892 ), 261.

${ }^{137}$ Larmer and Kennes, 'Rethinking the Katangese Secession'.

${ }^{138}$ Cf., however, Asani bin Katompa, 'L'opposition Sanga à Msiri'.

${ }^{139}$ FitzSimons, 'Sizing up the "Small Wars" of African Empire'. For a classic example of crude technological determinism, see Headrick, The Tools of Empire.

${ }^{140}$ Walter, Colonial Violence, 5.

${ }^{141}$ Macola, 'Introduction'.

\section{Bibliography}

Arnot, F.S. Garenganze; or, Seven Years' Pioneer Mission Work in Central Africa. London, 1889.

Arnot, F.S. Bihé and Garenganze; or, Four Years' Further Work and Travel in Central Africa. London, 1893.

Asani bin Katompa, K. 'L'opposition Sanga à Msiri et à l'administration coloniale Belge (1891-1911)'. Mémoire de licence en histoire. Université Nationale du Zaïre, Lubumbashi, 1977.

Briart, P. (ed. Dominique Ryelandt), Aux sources du fleuve Congo. Carnets du Katanga (1890-1893). Paris, 2003. Campbell, D. In the Heart of Bantuland. London, 1922.

Capello, H. and R. Ivens, De Angola á contra-costa. Descripção de uma viagem atravez do continente africano. 
Lisbon, 1886. 2 vols.

Delcommune, A. Vingt années de vie africaine. Brussels, 1922. 2 vols.

Delvaux, H. L'occupation du Katanga, 1891-1900. Notes et souvenirs du seul survivant. Elisabethville, 1950.

Echoes of Service (Bath), 1887-1900

FitzSimons, W. 'Sizing up the "Small Wars" of African Empire: An Assessment of the Context and Legacies of Nineteenth-Century Colonial Warfare'. Journal of African Military History, 2, no. 1 (2018): 63-78.

Giraud, V. Les lacs de l'Afrique équatoriale. Paris, 1890.

Gordon, D.M. 'The Abolition of the Slave Trade and the Transformation of the South-Central African Interior during the Nineteenth Century'. William and Mary Quarterly, 66, no. 4 (2009): 915-938

Headrick, D.H. The Tools of Empire: Technology and European Imperialism in the Nineteenth Century. New York and Oxford, 1981.

Iliffe, J. A Modern History of Tanganyika. Cambridge, 1979.

Jenniges, E. Dictionnaire français-kiluba. Brussels, 1909.

Larmer, M. and E. Kennes, 'Rethinking the Katangese Secession'. Journal of Imperial and Commonwealth History, 42, no. 4 (2014): 741-761.

Legros, H. Chasseurs d'ivoire. Une histoire du royaume yeke du Shaba (Zaïre). Brussels, 1996.

Le Marinel, P. Carnets de route dans l'Etat indépendant du Congo de 1887 à 1910. Brussels, 1991.

'Lettre de Mwenda II Mukanda Bantu à S.M. le Roi Albert à l'époque, Prince héritier de Belgique.

Traduit par A. Mwenda Munongo'. In Pages d'histoire yeke, edited by A. Mwenda Munongo. Lubumbashi, 1967.

Macola, G. The Kingdom of Kazembe: History and Politics in North-Eastern Zambia and Katanga to 1950. Hamburg, 2002.

Macola, G. The Gun in Central Africa: A History of Technology and Politics. Athens, OH, 2016.

Macola. G. (ed.), The Colonial Occupation of Katanga: The Personal Correspondence of Clément Brasseur, 1893-1897. Oxford, 2018.

Macola, G. 'Introduction: Brasseur's Papers and the African Roots of the Congo Free State'. In The Colonial Occupation of Katanga: The Personal Correspondence of Clément Brasseur, 1893-1897, edited by G. Macola. Oxford, 2018.

Morel, E.D. King Leopold's Rule in Africa. London, 1904.

Mwenda Munongo, A. (ed. and tr.), 'Chants historiques des Bayeke'. Problèmes Sociaux Congolais, 77 (1967): 35-139.

Nzongola-Ntalaja, G. The Congo from Leopold to Kabila: A People's History. London and New York, 2003.

Ranger, T.O. 'Connexions between "Primary Resistance Movements" and Modern Mass Nationalism in East and Central Africa'. Journal of African History, 9, nos. 3/4 (1968): 437-453, 631-641.

Reichard, P. 'Herr Paul Reichard: Bericht über seine reisen in Ostafrika und dem quellgebiet des Kongo'. Verhandlungen der Gesellschaft für Erdkunde zu Berlin, 13, no. 2 (1886): 107-125.

Reid, R.J. War in Pre-Colonial Eastern Africa: The Patterns \& Meanings of State-Level Conflict in the Nineteenth Century. Oxford, 2007.

Reid, R.J. 'Revisiting Primitive War: Perceptions of Violence and Race in History'. War and Society, 26, no. 2 (2007): 1-25.

Reid, R.J. 'Past and Presentism: The "Precolonial" and the Foreshortening of African History'. Journal of African History, 52, no. 2 (2011): 135-155.

Smith, R.S. Warfare and Diplomacy in Pre-Colonial West Africa. London, 1976.

Stairs, W. G. 'De Zanzibar au Katanga: Journal du Capitaine Stairs (1890-1891)'. Le Congo Illustré, 2, nos 23/25 (1893): 181-183, 189-191, 197-199.

Stengers, J. and J. Vansina. 'King Leopold's Congo, 1886-1908'. In The Cambridge History of Africa: Vol. VI, edited by R. Oliver and N. Sanderson. Cambridge, 1985.

Storey, W.K. Guns, Race and Power in Colonial South Africa. Cambridge, 2008.

Thornton, J. K. 'Placing the Military in African History: A Reflection'. Journal of African Military History, 1, nos. 1/2 (2017): 112-119.

Vandervort, B. Wars of Imperial Conquest in Africa, 1830-1914. London, 1998.

Verdick, E. Les premiers jours au Katanga (1890-1903). Brussels, 1952.

Walter, D. Colonial Violence: European Empires and the Use of Force. London, 2017. 